\title{
Fluctuating asymmetry and mortality in cultured oysters (Crassostrea gigas) in Marennes-Oléron basin
}

\author{
Marcel Fréchette ${ }^{\mathrm{a}, *}$, Philippe Goulletquer ${ }^{\mathrm{b}}$, Gaétan Daigle $^{\mathrm{c}}$ \\ ${ }^{a}$ Institut Maurice-Lamontagne, Ministère des Pêche et des Océans, C.P. 1000 Mont-Joli, QC, Canada G5H $3 Z 4$ \\ ${ }^{b}$ IFREMER, Laboratoire Conchylicole de Poitou-Charentes, BP 133, 17390 La Tremblade, France \\ ${ }^{c}$ Département de Mathématiques et de Statistique, Faculté des Sciences et de Génie, Pavillon Alexandre-Vachon, \\ Université Laval, Québec, QC, Canada G1K $7 P 4$
}

Received 13 December 2002; accepted 11 May 2003

\begin{abstract}
Japanese cupped oysters suffer summer mortality in many culture sites along the French Atlantic coast. To ascertain whether mortality might be associated with morphological features of the shells, we estimated fluctuating asymmetry (FA) of hatchery/nursery-produced oysters kept in culture bags in the intertidal. FA is defined as random variations from a perfect symmetry plane (bilateral or radial) in some morphological trait. FA increases with disruption of homeostasy during ontogeny and has both genetic and environmental determinants. We found significant differences in FA between dead and live oysters in two of our three study groups. Therefore, lack of developmental stability may be involved in the summer mortality syndrome of oysters. We also found indirect evidence that once acquired, FA patterns of shells are retained at least partially. Since FA likely appears early during ontogeny and is recorded in the shells, we hypothesise that it might be useful for forecasting the ability of spat to resist environmental stress.
\end{abstract}

(C) 2003 Éditions scientifiques et médicales Elsevier SAS and Ifremer/IRD/Inra/Cemagref. All rights reserved.

Résumé

Dissymétrie fluctuante et mortalité chez l'huître creuse (Crassostrea gigas) dans le bassin de Marennes-Oléron. Les élevages d'huître creuse du littoral atlantique français sont victimes de mortalité estivale importante et variable. Dans le but d'examiner si la mortalité estivale est associée à la morphologie des coquilles, nous estimons la dissymétrie fluctuante (DF ; « fluctuating asymmetry ») d'huîtres produites en écloserie et élevées en milieu intertidal. On définit la DF comme étant les variations aléatoires d'un ou plusieurs caractères morphologiques autour d'un plan de symétrie corporelle (bilatérale ou radiale) ; la DF augmente avec le degré de perturbation de l'homéostasie au cours de l'ontogénie. Elle dépend des caractéristiques génétiques des spécimens et des effets de l'environnement. Nos résultats indiquent que dans 2 des 3 groupes étudiés, les spécimens morts présentent la DF différente de celle des spécimens vivants. En conséquence, il se peut que des perturbations de l'homéostasie survenues au cours de l'ontogénie ne soient pas étrangères au syndrome de mortalité estivale des huîtres. Nous observons également qu'une fois acquise, la signature de la DF est conservée au moins partiellement. Puisque DF apparaît vraisemblablement de façon précoce au cours de l'ontogénie et qu'elle est conservée, ce paramètre pourrait être un indicateur prévisionnel de la capacité du naissain à résister aux stress environnementaux.

(C) 2003 Éditions scientifiques et médicales Elsevier SAS and Ifremer/IRD/Inra/Cemagref. All rights reserved.

Keywords: Aquaculture; Fluctuating asymmetry; Mortality; Oyster

\section{Introduction}

Severe non-predatory mortality has been reported in a large number of cultured bivalve populations. These populations may differ by orders of magnitude in size. At the large

\footnotetext{
* Corresponding author.

E-mail address: frechettem@dfo-mpo.gc.ca (M. Fréchette).
}

scale end of the spectrum, for instance, Japanese scallops Patinopecten yessoensis cultured in Mutsu Bay, suffered an estimated $40000 \mathrm{t}$ loss in the 1970s, presumably owing to competition-related mortality (Aoyama, 1989). In Marennes-Oléron basin (MOB), the oyster Crassostrea angulata supported large landings (ca. $40000 \mathrm{t} \mathrm{year}^{-1}$ ) before succumbing to parasitic outbreaks in the early 1970s and being replaced by a massive introduction of the Japanese 
cupped oyster, Crassostrea gigas (Thunberg) (Grizel and Héral, 1991). In contrast with the above, the small-scale mussel industry in Îles de la Madeleine, Québec, suffered more or less predictable summer mortality in the late 1980s and early 1990s (Myrand and Gaudreault, 1995).

Identification of causes of mass mortality and implementation of appropriate remedy may be straightforward in cases where mortality events are linked in some way to culture methods and management. Overstocking, for instance, is readily checked by reducing stocking density (e.g., Aoyama, 1989). Adjusting cultivation depth, choosing appropriate culture techniques or even switching to sturdier and byssusproducing species (in the case of scallops) may help reducing negative effects of waves (Freites et al., 1999). Choosing appropriate depth may also help minimising effects of epibionts (e.g., Claereboudt et al., 1994; Fréchette et al., 2000). Mortality caused by the protistan parasite Mikrocytos roughleyi to intertidally grown oysters Saccostrea glomerata was greatly reduced by installing oyster trays at appropriate intertidal level (Lauckner, 1983, in Smith et al., 2000). Using the well-known stock-site methodology for testing stock and site influences on growth and survival (Dickie et al., 1984; Mallet et al., 1990), Myrand and Gaudreault (1995) found that summer mortality of cultured mussels Mytilus edulis in Îles de la Madeleine could be reduced to negligible levels simply by collecting spat in a local body of water where mussels were not prone to summer mortality, and growing them in the usual culture sites. Similar conclusions were reached by Imai et al. (English abstract in Imai et al., 1965), who found oysters from Hiroshima Bay to be more resistant to summer mortality than local oysters from Matsushima Bay. In some cases, however, the incidence of mortality may be variable within sites (Goulletquer et al., 1998).

In other situations, however, mortality is associated with large-scale environmental properties, and cultivation and restoration methods may not be easily amenable to adjustment. For instance, many phytoplankton blooms may have quite harmful effects. A Ptychodiscus brevis bloom caused the bay scallop Argopecten irradians concentricus population of Bogue Sound, North Carolina, to crash by about one order of magnitude (Peterson and Summerson, 1992). In the laboratory, the dinoflagellate Gyrodinium aureolum caused severe mortality in hatchery/nursery-grown bay scallops (Smolowitz and Shumway, 1997). In some instances, harmful phytoplankton probably kill the Japanese pearl oyster Pinctada fucata (Tomaru et al., 2001). Besides trophic factors, temperature can be a pervasive factor in massive summer mortality. Intense mortality in the oyster Crassostrea virginica, for instance, is restricted to high temperature periods, which are favourable to growth of pathological agents in high salinity sites (English abstract in Kanno et al., 1965; Powell et al., 1994). In MOB, summer mortality of $C$. gigas varies from year to year, but is generally more severe in southernmost sites than in others (Soletchnik et al., 1999). Furthermore, mortality is more severe on bottom leases than higher in the water column. Off-bottom culture, however, is insufficient to avoid completely summer mortality.

Monitoring studies strongly suggest that summer mortality in C. gigas is a multi-factor process. Goulletquer et al. (1998), for instance, reported that summer mortality in MOB appeared to be linked to a sequence of situations involving first high food abundance leading to fast growth and high reproductive output, along with oxygen depletion and high water temperature during neap tides. During the following spring tides, long emersion time and stressful high air temperature, combined with exhaustion of glycogen reserves critically needed for anaerobiosis at low tide presumably added to the general stress level endured by the oysters. Parallel to this, the search of pathogenic causes have revealed a limited number of potential infectious agents, and challenge tests have shown that very similar strains may have quite different health consequences for oysters (Le Roux et al., 2002). Similar multi-factor processes in summer mortality of C. gigas were reported by Imai et al. (1968) and Cheney et al. (2000).

Since the oysters in MOB have little temporal or spatial refuge from summer mortality factors, it may be attempted to understand the role of environmental stress in summer mortality from the viewpoint of the environment only, a view which has support from results of case studies (e.g., Bricelj et al., 1992). This approach, however, assumes that the ability of the oysters to resist environmental stress is constant from year to year or independent of the individuals' developmental history. Oysters used for cultivation in MOB, however, are obtained from wild spat. In some years, stressful environmental conditions may increase developmental instability of spat and bear negative consequences for its future ability to resist environmental stress. Developmental instability is usually estimated using fluctuating asymmetry (FA; van Valen, 1962; Debat and David, 2001). FA is defined as random deviations from perfect symmetry (bilateral or radial) in some morphological trait. FA has both genetic and environmental determinants (Cadée, 2000). High FA has been related to lack of heterozygosity and disruption of coadapted gene complexes (Palmer and Strobeck, 1986; Clarke, 1993; Wilkins et al., 1995; Hochwender and Fritz, 1999). FA usually increases with increasing stress during ontogeny (Hochwender and Fritz, 1999; Badyaev et al., 2000; Hosken et al., 2000; Lens and Van Dongen, 2000; Kozlov et al., 2001) and is a convenient indicator of individual capacity to resist environmental stress (e.g., Brown and Bomberger Brown, 1998; Lens and Van Dongen, 2000; but see also Bjorksten et al., 2000). Recently, FA has been applied to the analysis of growth and survival of Iceland scallops Chlamys islandica grown in pearl nets for one year (Fréchette and Daigle, 2002). It was found that FA correlated with survivorship but not with growth patterns. Here we report preliminary observations of FA of $C$. gigas cultured in MOB in relation to resistance to summer mortality. In $C$. gigas shells are asymmetric, with the left valve being larger than the right valve (Legay et al., 2000). Therefore, shell 
asymmetry includes directional asymmetry and FA components. We focussed on FA patterns. Our study was done as a part of MOREST programme, a multi-disciplinary effort aiming at a better understanding of environmental, genetic, ecophysiological, immunological and pathological aspects of summer mortality of $C$. gigas along the French Atlantic coast (http://www.ifremer.fr/morest/).

\section{Methods}

C. gigas adults from MOB were spawned in the laboratory (one female, one male per family). Spat was raised in the laboratory (one larval tank per family), placed in culture bags (one bag per family) in June 2001 and grown in the intertidal near Ronce-les-Bains $\left(45.8^{\circ} \mathrm{N}, 1.2^{\circ} \mathrm{W}\right)$, France, on a single culture table. The oysters were brought back to the laboratory on 19 September 2001. We studied oysters from two families (families A and B) separately and from a blend of gametes of the 24 females and six males used to obtain the 16 families studied in MOREST programme (group C). Individuals with abnormal shells due to chambering or shells with culture bag mesh marks were rejected. All remaining oysters were studied, but dead oysters were retained in the study only if their valves were still articulated.

Asymmetry studies usually involve linear measurements of individuals. Oysters, however, are notoriously variable morphologically (Imai and Sakai, 1961). Therefore linear measurements are likely to be useless. Legay et al. (2000), however, found an elegant solution to this problem by using mass of the valves instead of linear measurements. In doing so, they implicitly integrated in a single estimate all possible estimations of asymmetry based on linear measurements. Our analysis was based on a similar strategy. The oysters were killed by heat shock at $70{ }^{\circ} \mathrm{C}$ for $2 \mathrm{~h}$ and washed in $47-50 \%$ sodium hypochlorite for $2 \mathrm{~h}$. The shells were dried at $70^{\circ} \mathrm{C}$ for $2 \mathrm{~h}$. The same treatment was applied a second and even a third time in cases where individuals did not open after a single treatment run. Shells were subsequently gently scraped to remove remaining epibionts without damaging delicate parts of the shells. The hinge ligament also was removed. All oysters, dead or alive, were treated as above. Each valve was weighted with $0.0001 \mathrm{~g}$ precision. Measurement error was examined by comparing FA as estimated by two independent measurements of valve mass (FA1 and FA2, respectively). We estimated the parameters of the relationship FA2 $=a+b$ FA 1 and found $a=0$ and $b=1.0013(N=44$, $\left.R^{2}=0.9997, P<0.0001\right)$. Therefore measurement error was negligible.

Two general growth models have been recognised (Mosimann and Campbell, 1988), which have critical implications for estimating FA (Graham et al., in press). The additive growth model occurs in cases where the tissue that generates growth does not change in size, as found in nails, feathers, teeth, scales, bristles, etc. In this case random growth errors may be additive (Mosimann and Campbell, 1988). The multiplicative growth model is appropriate in cases where growth results from tissue actively participating in the production of new tissue. In this case random growth errors are multiplicative. With the additive growth model, FA is appropriately measured as e.g. $F A=(L-R) /(L+R)$, where $L$ and $R$ are the size of the left (cupped valve) and right (flat valve) trait measured, respectively. With the multiplicative growth model, however, the appropriate formulation for FA is $F A=\ln (L / R)$, which removes size dependence in FA estimates (Graham et al., in press). The appropriate growth model may be ascertained from the analysis of the residuals of the relationship between the right and left sides. Positive scaling of residuals (tested following White, 1980) is strong evidence that growth is multiplicative (Graham et al., in press). Because shell asymmetry was directional, we estimated FA as the factor scores on the second principal component analysis carried out on unstandardised log-scale data, as proposed by Graham et al. (1998).

To check for any relationship between growth and FA, we tested the correlation between an index of individual size $(V)$ and $F A$. $V$ was calculated as $V=H\left[\left(A_{1}+A_{2}\right) / 2\right]\left[\left(B_{1}+B_{2}\right) / 2\right]$, where $H$ is thickness of the shell with both valves closed, $A$ and $B$ are the length and height of the valves, respectively, and the subscripts 1 and 2 stand for the left and the right valves, respectively. Linear measurements were made according to Fig. 1. Correlations between $V$ and $F A$ were not significant (Table 1). Therefore the data were tested using a two-way ANOVA with group and status (dead vs. alive) as fixed main effects.

To control for possible effects of repeated cleaning operations on shell mass, we washed a set of shells (right and left

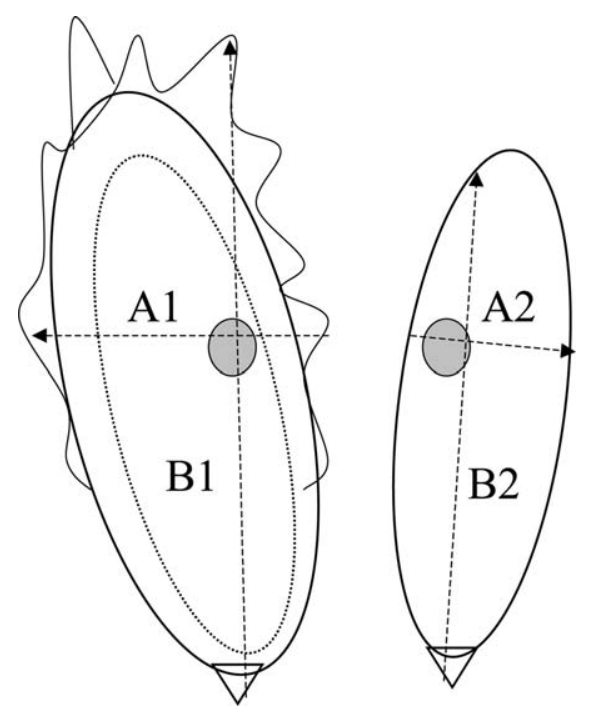

Fig. 1. Methodology for measuring the linear dimensions of the shells. A1, B1: length and height, respectively, of the left (cupped) valve. A2, B2: length and height, respectively, of the right (flat) valve. Height was measured from the umbo to the most distant point of the shell, provided that the axis of measurement overlapped with the muscle scar. Length was the widest dimension of the shell perpendicular to height, provided that the axis of measurement overlapped with the muscle scar. Width was determined by closing the valves and measuring the thickness of the whole oyster, with the caliper oriented in the height axis. This procedure allowed to make standardised measurements in spite of variability in shell shape. 
Table 1

Correlations (Pearson's $r$ ) between individual volume index and asymmetry of the shells according to group and status of oysters

\begin{tabular}{|c|c|c|c|c|c|c|}
\hline \multirow[t]{2}{*}{ Group } & \multicolumn{3}{|l|}{ Dead } & \multicolumn{3}{|l|}{ Live } \\
\hline & $N$ & $r$ & $P$ & $N$ & $r$ & $P$ \\
\hline Family A & 16 & 0.2579 & 0.3349 & 82 & -0.1226 & 0.2727 \\
\hline Family B & 99 & 0.0228 & 0.8224 & 126 & -0.0954 & 0.2839 \\
\hline Group C & 74 & -0.1980 & 0.0888 & 108 & -0.1414 & 0.1424 \\
\hline
\end{tabular}

valves) three times and measured the mass of the valves separately each time. We compared $F A$ after the second and third washes with $F A$ after a single wash. The effect of successive washes was tested using a repeated measures design with a first order autoregressive model for error structure. We found a significant effect of washing (test of main effect, $F=71.59 ; \mathrm{df}=2,140 ; P<0.0001)$. Each wash had a significant effect (first wash vs. second wash, $t=-10.43$, $\mathrm{df}=140, P<0.0001$; first wash vs. third wash, $t=-11.54$, df $=140, P<0.0001)$. Therefore $F A$ increased with successive washes. Consequently we adjusted a correction factor to the mass of each valve separately to account for mass loss of each valve after successive washes. The correction factor was computed as $\Delta m=m_{\mathrm{b}}-m_{\mathrm{a}}$, with $m_{\mathrm{b}}$ being valve mass after the first wash and $m_{\mathrm{a}}$ being valve mass after the second or the third wash, depending on the case. Knowing $m_{\mathrm{a}}$ and the number of washes given, the corrected initial valve mass was easily computed as the sum of $\Delta m$ and $m_{\mathrm{a}}$. Further details are given in Table 2.

\section{Results}

The relationship between the mass of the right and left valves is shown in Fig. 2. Clearly the relationships were linear for all groups. Residuals increased with increasing valve mass in family $\mathrm{B}\left(\chi^{2}=10.50, P=0.0052\right.$ and $\chi^{2}=10.15, P=0.0062$ for dead and live oysters, respectively; $\mathrm{df}=2)$ and group $\mathrm{C}\left(\chi^{2}=6.85, P=0.0326\right.$, and $\chi^{2}=8.94, P=0.0115$ for dead and live oysters, respectively; $\mathrm{df}=2$ ). The trend was similar but not significant in family A

Table 2

Parameter values for correcting for loss of valve mass following successive washes. Change in valve mass $(\Delta m)$ is fitted the statistical model $\Delta m=b+c m_{\mathrm{a}}{ }^{d}$, where $b, c$ and $d$ are parameters and $m_{\mathrm{a}}$ is valve mass after washing. MSE is mean square error and $N$ is number of observations. Numbers in parentheses are standard error of the estimates

\begin{tabular}{lllll}
\hline & Left valve & \multicolumn{3}{l}{ Right valve } \\
\cline { 2 - 5 } & Second wash & Third wash & Second wash & Third wash \\
\hline$b$ & 0.00555 & 0.00489 & -0.00694 & -0.00773 \\
& $(0.00289)$ & $(0.00633)$ & $(0.00849)$ & $(0.0109)$ \\
& & & & \\
$c$ & 0.00154 & 0.00477 & 0.00245 & 0.00208 \\
& $(0.00101)$ & $(0.00330)$ & $(0.00354)$ & $(0.00311)$ \\
& & & & \\
$d$ & 1.9226 & 1.5109 & 1.1549 & 1.4244 \\
& $(0.3427)$ & $(0.3567)$ & $(0.5325)$ & $(0.5673)$ \\
& & & & \\
MSE & 0.000103 & 0.000266 & 0.000213 & 0.000643 \\
$\mathrm{~N}$ & 72 & 72 & 70 & 70 \\
\hline
\end{tabular}
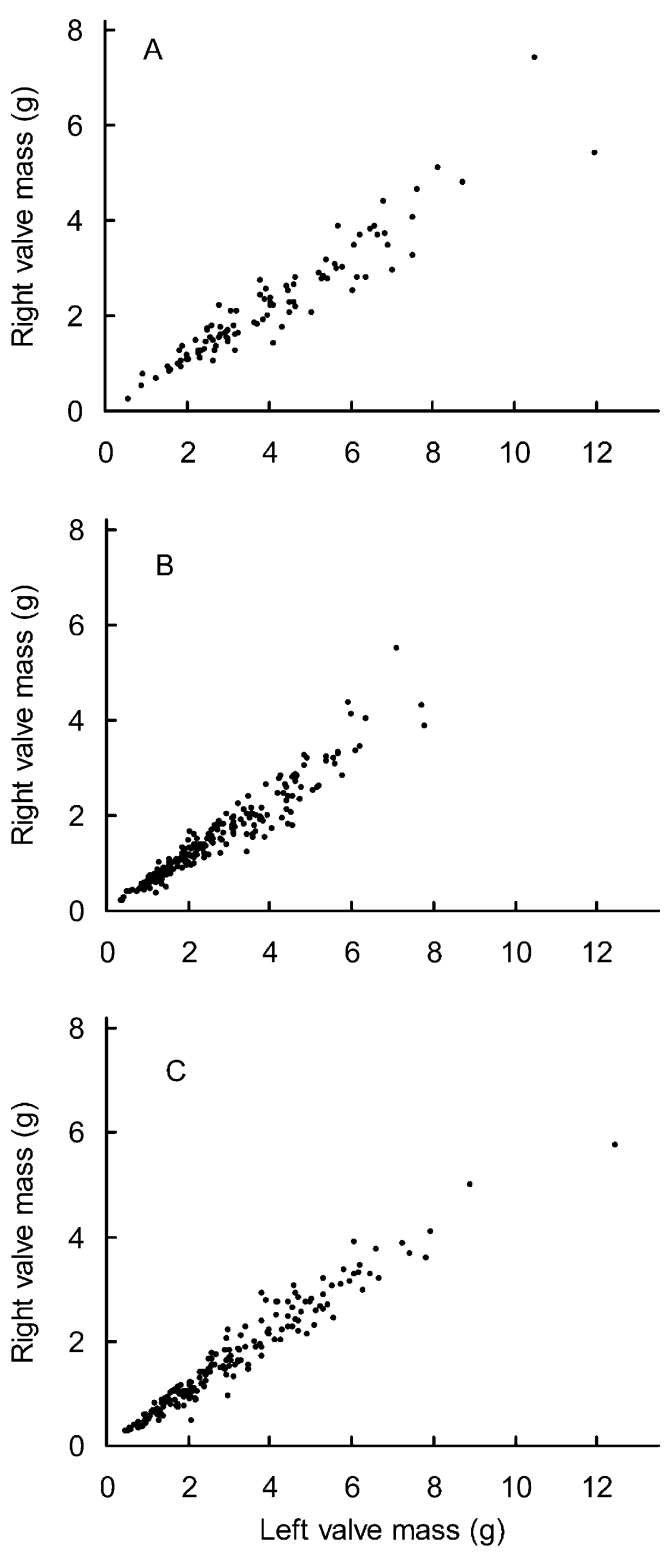

Fig. 2. Plot of right valve mass as a function of left valve mass for (A) family A, (B) family B and (C) group C. Data not corrected for successive washes.

$\left(\chi^{2}=2.62, P=0.2762\right.$, and $\chi^{2}=4.05, P=0.1320$ for dead and live oysters, respectively; $\mathrm{df}=2$ ). With log-transformed data, all groups were homoskedastic. The frequency of occurrence of asymmetry values of dead and live oysters is shown in Fig. 3A-C. In family A, there was clear evidence of differences in $F A$ between dead and live oysters. Family B, however, appeared to show no differences in $F A$ between dead and live individuals. Finally, in group $\mathrm{C}$ live oysters 

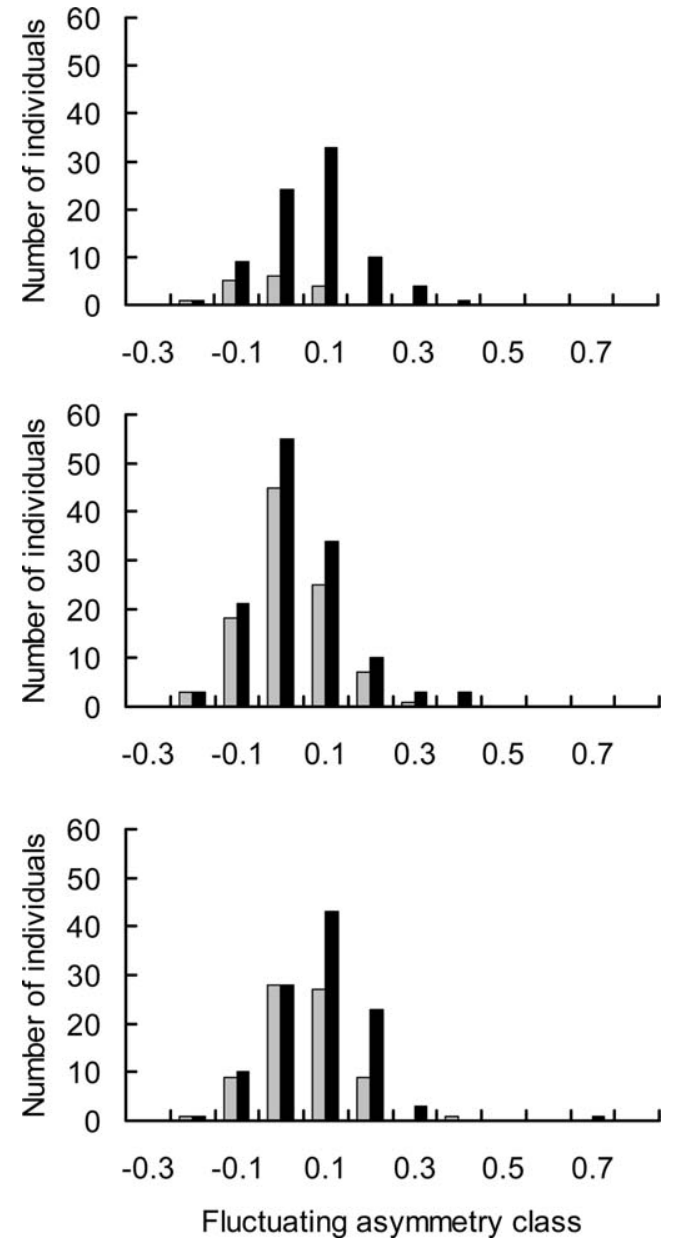

Fig. 3. Frequency of occurrence of asymmetry values in (A) family A, (B) family B and (C) group C. Light-grey bars are dead oysters. Black bars are live oysters. Data not corrected for successive washes. See Table 2 for statistical information on corrected data.

exhibited a tendency toward higher values than dead individuals. There were three individuals with high $F A$ values in groups $\mathrm{B}$ and $\mathrm{C}$. With all data included, residuals of the ANOVA were not normally distributed in some groups (Shapiro-Wilk test; family B, live oysters: $W=0.964004$, $N=129, P=0.0017$; group C, live oysters: $W=0.929907$, $N=109, P<0.0001$; for all groups pooled, $W=0.972558$, $P<0.0001, N=510)$. With these outliers removed, the assumption of normality was satisfied in all groups (ShapiroWilk test; family B, live oysters: $W=0.985883, N=127$, $P=0.2129$; group $\mathrm{C}$, live oysters: $W=0.995905, N=108$, $P=0.9885$; for all groups pooled, $W=0.993617, P=0.0309$, $N=507)$. These data were kept in Figs. 2 and 3. ANOVA revealed a borderline interaction between group and status ( $P=0.0569$; Table 3$)$. With the three outliers removed, the interaction was significant $(P=0.0242)$. Therefore we accepted the interaction as significant and tested the least squares means of all sets of oysters using all the data. FA of dead and live oysters was different for family A and group C, but not for family B (Table 4; with the three outliers removed, results of statistical analyses were essentially the same).
Table 3

Effect of group and status of oysters on asymmetry of the shells. ANOVA (SAS, PROC MIXED)

\begin{tabular}{llll}
\hline & Effect & & \\
\cline { 2 - 4 } & df & $F^{\mathrm{a}}$ & $P$ \\
\hline Group & 2 & 9.89 & $<0.0001$ \\
Status & 1 & 23.80 & $<0.0001$ \\
Group $\times$ status & 2 & 2.88 & 0.0569 \\
\hline
\end{tabular}

${ }^{\text {a}}$ Denominator degree of freedom is 504 for all tests.

Table 4

Mean of shell fluctuating asymmetry (least squares means; ANOVA). Groups with common symbols are not significantly different from each other $(\alpha=0.05)$. Numbers in parentheses are standard errors

\begin{tabular}{llll}
\hline & Family A & Family B & Group C \\
\hline Dead & $-0.07905^{*}$ & $-0.03661^{*}, \boldsymbol{A}$ & $-0.00121^{\dagger, \ddagger}$ \\
& $(0.02568)$ & $(0.01032)$ & $(0.01186)$ \\
Live & $0.02268^{\#, \ddagger}$ & $-0.00991^{\dagger,}$ & $0.04036^{\#}$ \\
& $(0.01134)$ & $(0.00905)$ & $(0.00984)$ \\
\hline
\end{tabular}

\section{Discussion}

The results found in the present study clearly suggest that the fate of hatchery/nursery produced $C$. gigas grown in the intertidal is related to FA to some extent, with dead oysters displaying lower FA. Since FA is related to disruption of homeostasy, lack of developmental stability may be involved in the summer mortality syndrome of oysters. This may explain the difficulty of pointing out single mechanistic causes to the syndrome (e.g., Goulletquer et al., 1998; Le Roux et al., 2002).

Considering that group $\mathrm{C}$, which was a genetic pool of the spawners used in the MOREST programme in 2001 exhibited a significant link between FA and status, it seems reasonable to conclude that the link between FA and status has some generality. There were, however, differences among groups, with status having no effect in family $\mathrm{B}$, as opposed to family A and group C (Table 4). There is conflicting evidence about the relative importance of genetic and environmental causes in generating FA. On the one hand, genetic factors such as disruption of co-adapted gene complexes (Clarke, 1993; Wilkins et al., 1995; Hochwender and Fritz, 1999) and lack of heterozygosity (see references in Palmer and Strobeck, 1986) contribute to higher FA, although Vøllestad et al. (1999) found no relationship between FA and heterozygosity. Cadée (2000) found variability in the relative importance of genetic and environmental effects, with more stressful conditions leading to a greater relative importance of environmental effects. On the other hand, FA has also been found to correlate with parasitism (Møller, 1996; but see Ward et al., 1998). Severity of parasitic infections is probably more a consequence of developmental instability (as estimated by FA) than a cause (Thomas et al., 1998). FA has been found to increase in response to environmental stress during ontogeny (Hochwender and Fritz, 1999; Badyaev et al., 2000; Hosken et al., 2000; Lens and Van Dongen, 2000). A further mechanism for increasing FA, at least in plants, is competition for 
resources because of limited energy for maintaining homeostasis (as estimated by FA) (Alados et al., 2001; Kozlov et al., 2001). Therefore, FA appears to reflect the general quality of the genetic makeup of individuals but also epigenetic effects of stressful conditions during growth. The oysters in the present study were produced in common hatchery/nursery facilities and grown on a single culture table at constant intertidal height. These conditions are likely to minimise heterogeneity in growth conditions among groups and appear to support the hypothesis that variability in FA and status were related to genetic differences among groups. This is inconclusive, however, first because the bags and larval tanks were not duplicated, and second because no attempt was made to manipulate FA through the application of variable environmental stresses. Therefore, both genetic and nongenetic factors might have influenced FA and resistance to summer mortality. This is not to say that genetic influences do not impact the ability to resist summer mortality. Mortality levels of $C$. gigas families selected for heat resistance correlated well between the field and the laboratory (Beattie et al., 1980). In the present situation, however, environmental and genetic influences cannot be sorted out.

A further point concerns the time at which FA is generated-assuming that environmental control is dominant over genetic influences-and its stability through time. In many cases, compensatory growth may occur and damp individual asymmetry events through time (e.g., Collin, 1997; see also references in Freeman et al., 2003, p. 372; Palmer and Strobeck, 2003, p. 284). Other cases have been found where asymmetry is stable through time (e.g., snow crab: Chippindale and Palmer, 1993; barn swallow: Shykoff and Møller, 1999). In the present study, FA appeared to be generated during early ontogeny and to persist to some extent throughout life, because heteroskedasticity in the plots of right valve mass vs. left valve mass (Fig. 2) imply a multiplicative growth model, with shell growth patterns depending on past growth events (Mosimann and Campbell, 1988; Graham et al., 1998). In this case, FA patterns established early in life will be reflected in future FA patterns. If the relationship between FA and survivorship holds tightly enough, it follows that future survivorship of adults may be forecasted from FA of spat. Our results provide some support to the hypothesis that FA is stable once acquired in family $\mathrm{B}$ and group C, but is inconclusive in the case of family A. Further evidence is needed to provide a firm basis for forecasting survivorship from FA patterns.

The significance of early events, however, is supported by evidence that spatial organisation of molecular processes early after fertilisation is central to normal embryonic development (Atlan, 1999; Simmonds et al., 2001; Wilkie and Davis, 2001). Any disruption of spatial organisation of molecular gradients within early embryos is likely to be reflected in embryological processes and in later anatomical characteristics, which will translate into increased FA. Internal organisation of oocytes and early embryos may be disrupted by small gradients in a number of environmental variables. One such variable may be shear stress exerted on gametes and young embryos by turbulent eddies (Mead and Denny, 1995). They found that high shear stress could reduce fertilisation efficiency but also had negative effects on development and survival of embryos, especially if shear stress was applied at fertilisation. Shear stress may impact cell functioning of a number of similar-sized organisms (Juhl et al., 2001). Therefore, effects of shear stress on similar-sized organisms potentially may be widespread. Mixing of gamete solutions to promote fertilisation is standard practice in hatcheries. Increasing turbulence in larval cultures is also standard practice. The amount of shear stress applied in such operations may be generally profitable at low shear stress levels, but clearly could be detrimental at high levels. Future resistance to environmental stress (e.g., temperature) may unknowingly be jeopardised because of loss of homeostasis. On the other hand, later developmental processes may depend on effects induced by shear stress and related mechanical forces (as seen in lung development, for instance; Wirtz and Dobbs, 2000). Finally there is evidence that FA may respond to environmental stress or to intraspecific competition (Kozlov et al., 2001) later in an individual's life cycle. The issue could be critical for quality control of hatchery spat batches. If FA is determined early in life and if the link holds in the long term, early determination of FA may provide a convenient tool for early warning of potential homeostatic problems. Furthermore, early determination of FA may provide a basis for pricing various spat batches according to their expected capability to resist summer mortality. Cost of spat may amount to a significant portion of total production costs (e.g., Spencer et al., 1985).

Abnormal shell calcification appears to be part of the summer mortality syndrome in many cases (see references in Comps et al., 2001). In a case study of summer mortality in C. virginica, for instance, Bricelj et al. (1992) found anomalous conchiolin deposits on either the right or the left valve, or on both valves, and a tendency of the left (cupped) valve to extend beyond the edge of the right valve. However, we did not notice anomalous shell deposition in our samples-besides chambering or meshing. Whether anomalous extension of either valve occurred in our samples and was involved in mortality and FA is unclear. In a context of forecasting spat survival, the critical issue here is that early measurements of FA be correlated with future anomalous extension of valves, a point which cannot be ascertained with the present data.

A source of concern in our study may be the unknown, but potentially long (i.e., possibly nearly two months) period that dead shells remained in the culture bags before being sampled. A possible bias likely to occur in the case of differential longevity is that dead shells may have eroded after death. If right and left valves eroded at different rates, this might have caused bias in comparisons of the effect of status. It is clear, however, that successive washes resulted in increased $F A$ values. Assuming that successive washes acted as a proxy of the effect of progressive shell dissolution and 
erosion, we conclude that these processes acted to increase apparent FA, if anything. Given that significant effects were attributable to mean $F A$ being lower in dead oysters than in live oysters, we conclude that any redissolution bias in FA of dead shells would have resulted in decreasing differences between dead and live individuals, thus favouring a conservative interpretation of the statistical analyses. The MSE values in Table 2 suggest that the correction for the effect of washing was increasingly variable with successive washes. This indicates that successive washes not only change the average $F A$, but also its variability, presumably owing to added valve wear caused by extra manipulations. Therefore, if washes reflect the effect of shell dissolution of dead oysters accurately, the variability of $F A$ values of dead oysters was probably inflated, but to an unknown extent. This potential effect again favoured a conservative interpretation of the statistical analyses.

Our results may relate to carrying capacity studies in two ways. First, carrying capacity models usually incorporate mortality as a constant process (e.g., Bacher et al., 1998). If the relationship between FA, environmental stress and mortality were known, environmental forcing on densityindependent mortality could be included in such models. Second, Alados et al. (2001) and Kozlov et al. (2001) reported significant relationships between FA and growth. Therefore, knowledge of FA distribution in modelled populations may allow to include individual variability in growth rate. As noted earlier, however, the relationship between FA and individual size was not significant. Legay et al. (2000) reported a positive relationship between a commonly used measure of FA (which they called "dissymétrie relative") and individual size in $C$. gigas. This is inconsistent with our results and may have to do with the methodology used by Legay et al. (2000). They estimated FA as $(L-R) / 0.5(L+R)$, which is inappropriate with multiplicative growth (which is probably the rule in C. gigas; Fig. 2B,C) and directional asymmetry (Graham et al., 1998, in press). Therefore, for the time being we conclude that there is no relationship between FA and growth in $C$. gigas.

FA appears particularly appealing for forecasting spat ability to resist environmental stress because it seems to appear early in ontogeny, to be stable through time and is based on simple measurements. A further point is that shells of dead individuals retain useful information. At the present time, however, further evidence is required to support the inferences relative to timing and stability of FA in C. gigas and establish the link between survivorship and FA on more solid ground.

\section{Acknowledgements}

This work was supported by Région Poitou-Charentes. This is a contribution to MOREST programme (MORtalité ESTivale de l'huître creuse).

We thank J. Graham for discussions about estimating FA and two anonymous referees for constructive comments.
P. Soletchnik provided us with samples. P. Soletchnik, O. Le Moine and $\mathrm{C}$. Bacher commented an earlier version of this manuscript. We are grateful also to L. Degremont and numerous colleagues at LCPC for producing and raising the oysters until their installation in the field.

\section{References}

Alados, C.L., Navarro, T., Escós, J., Cabezudo, B., Emlen, J.M., 2001. Translational and fluctuating asymmetry as tools to detect stress in stress-adapted and nonadapted plants. Int. J. Plant Sci. 162, 607-616.

Aoyama, S., 1989. The Mutsu Bay scallop fisheries: scallop culture, stock enhancement, and resource management. In: Caddy, J.F. (Ed.), Marine invertebrate fisheries: their assessment and management. J. Wiley, New York, pp. 525-539.

Atlan, H., 1999. La fin du "tout génétique"? Vers de nouveaux paradigmes en biologie. INRA, Paris.

Bacher, C., Duarte, P., Ferreira, J.G., Héral, M., Raillard, O., 1998. Assessment and comparison of the Marennes-Oléron Bay (France) and Carlingford Lough (Ireland) carrying capacity with ecosystem models. Aquat. Ecol. 31, 379-394.

Badyaev, A.V., Foresman, K.R., Fernandes, M.V., 2000. Stress and developmental stability: vegetation removal causes increased fluctuating asymmetry in shrews. Ecology 81, 336-345.

Beattie, J.H., Chew, K.K., Hershberger, W.K., 1980. Differential survival of selected strains of Pacific oysters (Crassostrea gigas) during summer mortality. Proc. Nat. Shellfish Assoc. 70, 184-189.

Bjorksten, T., Fowler, K., Pomiakowski, A., 2000. What does sexual trait FA tell us about stress? Trends Ecol. Evol. 15, 163-166.

Bricelj, V.M., Ford, S.E., Borrero, F.J., Perkins, F.O., Rivara, G., 1992. R.E., Elston, R.A., Chang, J., 1992. Unexplained mortalities of hatcheryreared, juvenile oysters, Crassostrea virginica (Gmelin). J. Shellfish Res. 11, 331-347.

Brown, C.R., Bomberger Brown, M., 1998. Intense natural selection on body size and wing and tail asymmetry in cliff swallows during severe weather. Evolution 52, 1461-1475.

Cadée, N., 2000. Genetic and environmental effects on morphology and fluctuating asymmetry in nestling barn swallows. J. Evol. Biol. 13, 359-370.

Cheney, D.P., MacDonald, B.F., Elston, R.A., 2000. Summer mortality of Pacific oysters, Crassostrea gigas (Thünberg): Initial findings on multiple environmental stressors in Puget Sound, Washington, 1998. J. Shellfish Res. 19, 353-359.

Chippindale, A.K., Palmer, A.R., 1993. Persistence of subtle departures from symmetry over multiple molts in individual brachyuran crabs: relevance to developmental stability. Genetica 89, 185-199.

Claereboudt, M.R., Bureau, D., Côté, J., Himmelman, J.H., 1994. Fouling development and its effect on the growth of juvenile giant scallops (Placopecten magellanicus) in suspended culture. Aquaculture 121, 327-342.

Clarke, G.M., 1993. The genetic basis of developmental stability. I. Relationships between stability, heterozygosity and genomic coadaptation. Genetica 89, 15-23.

Collin, R., 1997. Ontogeny of subtle skeletal asymmetries in individual larvae of the sand dollar Dendraster excentricus. Evolution 51, 9991005 .

Comps, M., Herbaut, C., Fougerouse, A., Laporte, F., 2001. Progress in pathological characterization of Syndrome 85 in the black-lip pearl oyster Pinctada margaritifera. Aquat. Living Resour 14, 195-202.

Debat, V., David, P., 2001. Mapping phenotypes: canalisation, plasticity and developmental stability. Trends Ecol. Evol. 16, 555-561.

Dickie, L.M., Boudreau, P.R., Freeman, K.R., 1984. Influences of stock and site on growth and mortality in the blue mussel (Mytilus edulis). Can. J. Fish. Aquat. Sci. 41, 134-140.

Fréchette, M., Daigle, G., 2002. Growth, survival and fluctuating asymmetry of Iceland scallops in a test of density-dependent growth in a natural bed. J. Exp. Mar. Biol. Ecol. 270, 73-91. 
Fréchette, M., Gaudet, M., Vigneau, S., 2000. Estimating optimal population density for intermediate culture of scallops in spat collector bags. Aquaculture 183, 105-124.

Freeman, C.D., Graham, J.H., Emlen, J.M., Tracy, M., Hough, R.A., Alados, C.L., Escós, J., 2003. Plant developmental instability: new measures, applications, and regulation. In: Polak, M. (Ed.), Developmental instability. Causes and consequences. Oxford University Press, pp. 367386.

Freites, L., Côté, J., Himmelman, J., Lodeiros, C.J., 1999. Effects of wave action on the growth and survival of the scallops Euvola ziczac and Lyropecten nodosus in suspended culture. J. Exp. Mar. Biol. Ecol. 239, $47-59$.

Goulletquer, P., Soletchnik, P., Le Moine, O., Razet, D., Geairon, P., Faury, N., Taillade, S., 1998. Summer mortality of the Pacific cupped oyster Crassostrea gigas in the Bay of Marennes Oléron (France). ICES CM 1998/CC (14).

Graham, J.H., Emlen, J.M., Freeman, D.C., Leamy, L.J., Kieser, J.A., 1998. Directional asymmetry and the measurement of developmental instability. Biol. J. Linn. Soc. 64, 1-16.

Graham, J.H., Shimizu, K., Emlen, J.M., Freeman, C.D., Merkel, J., 2003. Growth models and the expected distribution of fluctuating asymmetry. Biol. J. Linn. Soc. in press.

Grizel, H., Héral, M., 1991. Introduction into France of the Japanese oyster Crassostrea gigas. J. Cons. Int. Explor. Mer 47, 399-403.

Hochwender, C.G., Fritz, R.S., 1999. Fluctuating asymmetry in a Salix hybrid system: the importance of genetic versus environmental causes. Evolution 53, 408-416.

Hosken, D.J., Blanckenhorn, W.U., Ward, P.I., 2000. Developmental stability in yellow dung flies (Scathophaga stercoraria): fluctuating asymmetry, heterozygosity and environmental stress. J. Evol. Biol. 13, 919-926.

Imai, T., Sakai, S., 1961. Study of breeding of Japanese oyster, Crassostrea gigas. Tohoku J. Agr. Res. 12, 125-171.

Imai, T., Numachi, K.-I., Oizumi, J., Sato, S., 1965. Studies on the mass mortality of the oyster in Matsuchima Bay II. Search for the cause of mass mortality and the possibility to prevent it by transplantation experiment. Bull. Tohoku Reg. Fish. Res. Lab. 25, 27-38.

Imai, T., Mori, K., Sugawara, Y., Tamate, H., Oizumi, J., Itikawa, O., 1968. Studies on the mass mortality of oysters in Matsushima Bay VII. Pathogenetic investigation. Tohoku J. Agr. Res. 19, 250-264.

Juhl, A.R., Trainer, V.L., Latz, M.I., 2001. Effect of fluid shear and irradiance on population growth and cellular toxin content of the dinoflagellate Alexandrium fundyense. Limnol. Oceanogr. 46, 758-764.

Kanno, H., Sasaki, M., Sakurai, Y., Watanabe, T., Suzuki, K., 1965. Studies on the mass mortality of the oyster in Matsushima Bay I. General aspects of the mass mortality of the oyster in Matsushima Bay and its environmental conditions. Bull. Tohoku Reg. Fish. Res. Lab. 25, 1-26.

Kozlov, M.V., Zvereva, E.L., Niemelä, P., 2001. Shoot fluctuating asymmetry: a new and objective stress index in Norway spruce (Picea abies). Can. J. Forest Res. 31, 1289-1291.

Lauckner, G., 1983. Diseases of Mollusca: bivalvia. In: Kinne, O. (Ed.), Diseases of marine animals. Biologische Anstalt Helgoland, Hamburg, vol. 2, pp. 447-961.

Le Roux, F., Gay, M., Lambert, C., Waechter, M., Poubalanne, S., Chollet, B., Nicolas, J.-L., Berthe, F., 2002. Comparative analysis of Vibrio splendidus-related strains isolated during Crassostrea gigas mortality events. Aquat. Living Resour. 15, 251-258.

Legay, J.-M., Heizmann, A., Thiriot-Quiévreux, C., 2000. Dissymétrie et taux de croissance des valves de la coquille chez les jeunes huîtres de Crassostrea gigas Thünberg. C.R. Acad. Sci. (Paris) Ser III Sci. Vie 323, $537-542$.

Lens, L., Van Dongen, S., 2000. Fluctuating and directional asymmetry in natural bird populations exposed to different levels of habitat disturbance, as revealed by mixture analysis. Ecol. Lett. 3, 516-522.

Mallet, A.L., Carver, C.E.A., Freeman, K.R., 1990. Summer mortality of the blue mussel in eastern Canada: spatial, temporal, stock and age variation. Mar. Ecol. Prog. Ser. 67, 35-41.
Mead, K.S., Denny, M.W., 1995. The effects of hydrodynamic shear stress on fertilisation and early development of the purple sea urchin Strongylocentrotus purpuratus. Biol. Bull. (Woods Hole) 188, 46-56.

Møller, A.P., 1996. Parasitism and developmental instability of hosts: a review. Oikos 77, 189-196.

Mosimann, J.E., Campbell, G., 1988. Applications in biology: simple growth models. In: Crow, E.L., Shimizu, K. (Eds.), Lognormal distributions: theory and applications. Marcel Dekker, New York, pp. 287-302.

Myrand, B., Gaudreault, J., 1995. Summer mortality of blue mussels (Mytilus edulis Linneaus, 1758) in the Magdalen Islands (Southern Gulf of St Lawrence, Canada). J. Shellfish Res. 14, 395-404.

Palmer, A.R., Strobeck, C., 1986. Fluctuating asymmetry: measurement, analysis, pattern. Ann. Rev. Ecol. Syst. 17, 391-421.

Palmer, R.A., Strobeck, C., 2003. Fluctuating asymmetry analyses revisited. In: Polak, M. (Ed.), Developmental instability. Causes and consequences. Oxford University Press, pp. 279-319.

Peterson, C.H., Summerson, H.C., 1992. Basin-scale coherence of population dynamics of an exploited marine invertebrate, the bay scallop: implications of recruitment limitation. Mar. Ecol. Prog. Ser. 90, 257272.

Powell, E.N., Klinck, J.M., Hofmann, E.E., Ray, S.M., 1994. Modeling oyster populations. IV: Rates of mortality, population crashes, and management. Fish. Bull. 92, 347-373.

Shykoff, J.A., Møller, A.P., 1999. Fitness and asymmetry under different environmental conditions in the barn swallow. Oikos 86, 152-158.

Simmonds, A.J., dosSantos, G., Livne-Bar, I., Krause, H.M., 2001. Apical localization of wingless transcripts is required for wingless signaling. Cell 105, 197-207.

Smith, I.R., Nell, J.A., Adlard, R., 2000. The effect of growing level and growing method on winter mortality, Mikrocytos roughleyi, in diploid and triploid Sydney rock oysters, Saccostrea glomerata. Aquaculture $185,197-205$.

Smolowitz, R., Shumway, S.E., 1997. Possible cytotoxic effects of the dinoflagellate, Gyrodinium aureolum, on juvenile bivalve molluscs. Aquacult. Int. 5, 291-300.

Soletchnik, P., Le Moine, O., Faury, N., Razet, D., Geairon, P., Goulletquer, P., 1999. Mortalité de l'huître Crassostrea gigas dans le bassin de Marennes-Oléron : étude de la variabilité spatiale de son environnement et de sa biologie par un système d'informations géographiques (SIG). Aquat. Living Resour. 12, 131-143.

Spencer, B.E., Gough, C.J., Thomas, M.J., 1985. A strategy for growing hatchery-reared Pacific oysters (Crassostrea gigas Thünberg) to market size-experiments and observations on small-scale trials. Aquaculture $50,175-192$.

Thomas, F., Ward, D.F., Poulin, R., 1998. Fluctuating asymmetry in an insect host: a big role for big parasites? Ecol. Lett. 1, 112-117.

Tomaru, Y., Kawabata, Z., Nakano, S., 2001. Mass mortality of the Japanese pearl oyster Pinctada fucata martensii in relation to water temperature, chlorophyll $a$ and phytoplankton composition. Dis. Aquat. Org. 44, 61-68.

van Valen, L., 1962. A study of fluctuating asymmetry. Evolution 16, 125142.

Vøllestad, L.A., Hindar, K., Møller, A.P., 1999. A meta-analysis of fluctuating asymmetry in relation to heterozygosity. Heredity 83, 206-218.

Ward, D.F., Thomas, F., Poulin, R., 1998. Fluctuating asymmetry and parasitism in six New Zealand insects. Acta Oecol. 19, 409-412.

White, H., 1980. A heteroskedasticity-consistent covariance matrix estimator and a direct test for heteroskedasticity. Econometrica 48, 817-838.

Wilkie, G.S., Davis, I., 2001. Drosophila wingless and pair-rule transcripts localize apically in dynein-mediated transport of RNA particles. Cell 105, 209-219.

Wilkins, N.P., Gosling, E., Curatolo, A., Linnane, A., Jordan, C., Courtney, H.P., 1995. Fluctuating asymmetry in Atlantic salmon, European trout and their hybrids, including triploids. Aquaculture 137, 77-85.

Wirtz, H.R., Dobbs, L.G., 2000. The effects of mechanical forces on lung functions. Respir. Physiol. 119, 1-17. 